Удк 311:33

Tamara Merkulova, Borys Koval

V.N. Karazin Kharkiv National University

4 Svobody Sq., 61022, Kharkiv, Ukraine

E-mail: tamara.merkulova@karazin.ua, ORCID: https://orcid.org/0000-0002-3507-5593

\title{
TRUST AND SOCIO-ECONOMIC INDICATORS: MODEL INCLUDING RELIGION FACTOR
}

The article is concerned with the following issues: definitions, indicators of trust were reviewed; the working hypotheses of the research were formed; the choice of factors related to the trust indices was made; cluster analysis of the relationship between individual trust indices and economic indicators was carried out; a correlation analysis of the relationship between individual trust indices and socio-cultural indicators was conducted; a neural network for modeling the general index of trust based on a well-founded set of economic and socio-cultural indicators was developed.

The hypothesis about the influence of socio-cultural factors on trust and out of which there was distinguished a relation to a specific religion. By means of correlation analysis and neural networks, it was shown that Protestantism and Catholicism are the most significant religions that affect the general index of interpersonal trust. However, atheism has a more significant impact.

Following 198 observations, each of which represented the country for a given year in the period from 1995 to 2014, the neural network produced satisfactory results in forecasting the total trust index on the basis of the following factors: GDP per capita, GINI coefficient, atheism (percentage of population, support such an attitude to religion). The neural network recognized $89.9 \%$ of the data and $90 \%$ of the test set indicating that the network got adjusted and could be used for modeling. The scatter diagram for a $5 \%$ error indicates that most of the data is within the required value. But it should be noted, that the model overestimates trust in Ukraine at the end of the analyzed period. This gives grounds for the assumption that in Ukraine there are additional factors that negatively affect interpersonal trust.

Keywords: interpersonal trust, institutional trust, correlation analysis, cluster analysis, neural network modeling.

JEL Classification: A13, C01, C38, C45.

Т. В. Меркулова, Б. С. Коваль

Харківський національний університет імені В. Н. Каразіна

пл. Свободи, 4, м. Харків, 61022, Україна

E-mail: tamara.merkulova@karazin.ua, ORCID: https://orcid.org/0000-0002-3507-5593

\section{ДОВІРА ТА СОЦІАЛЬНО-ЕКОНОМІЧНІ ПОКАЗНИКИ: МОДЕЛЬ 3 УРАХУВАННЯМ ФАКТОРА РЕЛІГІЇ}

У роботі розглянуто наступні питання: проведено огляд дефініцій, показників довіри; сформульовані робочі гіпотези дослідження; здійснено вибір факторів, що пов'язані з індексами довіри; проведено кластерний аналіз взаємозв'язку між окремими індексами довіри та економічними показниками; проведено кореляційний аналіз взаємозв'язку між окремими індексами довіри та соціально-культурними показниками; розроблена нейронна мережа для моделювання загального індексу довіри на підставі обґрунтованого набору економічних та соціо-культурних показників.

Була перевірена гіпотеза про вплив на довіру соціально-культурних фракторів, серед яких було виділено відношення до певної релігії. За допомогою кореляційного аналізу та нейросітьового моделювання було показано, що найбільш значущими релігіями, які впливають на загальній індекс міжособистісної довіри, є протестантизм та католицтво. Однак більш вагомий вплив має атеїзм.

Розроблена за даними 198 спостережень, кожне з яких являло собою країну світу за певний рік в період 1995-2014рр., нейромережева модель дає задовільні результати у прогнозуванні загального індексу довіри на підставі факторів: ВВП на душу населення, коефіцієнт GINI, атеїзм (відсоток населення, що підтримують таке ставлення до релігії). Нейронна мережа розпізнала $89,9 \%$ даних і $90 \%$ тестової множини, що говорить про те, що мережа настроїлася і може бути використана для моделювання. Діаграма розсіювання для 5\% помилки, показує, що більша частини даних знаходиться у припустимому інтервалі. Але слід відмітить, що модель дає завищену оцінку довіри для України на кінці періоду, що

(c) Merkulova T. V., Koval B. S., 2018 
аналізувався. Це дає підстави для припущення, що в Україні діють ще додаткові фактори, що негативно впливають на міжособистісну довіру.

Ключові слова: міжособистісна довіра, інституційна довіра, кореляційний аналіз, кластерний аналіз, нейромережеве моделювання.

JEL Classification: A13, C01, C38, C45.

\author{
Т. В. Меркулова, Б. С. Коваль \\ Харьковский национальный университет имени В. Н. Каразина, \\ пл. Свободы, 4, 61022, Харьков, Украина \\ E-mail: tamara.merkulova@karazin.ua, ORCID: https://orcid.org/0000-0002-3507-5593

\section{ДОВЕРИЕ И СОЦИАЛЬНО-ЭКОНОМИЧЕСКИЕ ПОКАЗАТЕЛИ: МОДЕЛЬ С УЧЕТОМ ФАКТОРА РЕЛИГИИ}

В работе рассмотрены следующие вопросы: проведен осмотр дефиниций, показателей доверия; сформулированы рабочие гипотезы исследования; осуществлен выбор факторов, связанных с индексами доверия; проведено кластерный анализ взаимосвязи между отдельными индексами доверия $и$ экономическими показателями; проведен корреляционный анализ взаимосвязи между отдельными индексами доверия и социально-культурными показателями; разработана нейронная сеть для моделирования общего индекса доверия на основании обоснованного набора экономических и социокультурных показателей.

Была проверена гипотеза о влиянии на доверия социально-культурных факторов, среди которых был выделен отношение к определенной религии. С помощью корреляционного анализа и нейросетевого моделирования было показано, что наиболее значимыми религиями, которые влияют на общей индекс межличностного доверия, является протестантизм и католичество. Однако более существенное влияние имеет атеизм.

Разработанная по данным 198 наблюдений, каждое из которых представляло собой страну за определенный год в период 1995 - 2014, нейросетевая модель дает удовлетворительные результаты в прогнозировании общего индекса доверия на основании факторов: ВВП на душу населения, коэффициент GINI, атеизм (процент населения, поддерживают такое отношение к религии). Нейронная сеть распознала 89,9\% данных и 90\% тестовой множества, что говорит о том, что сеть настроилась и может быть использована для моделирования. Диаграмма рассеивания для $5 \%$ ошибки, показывает, что большая часть данных находится в допустимом интервале. Но следует отметит, что модель дает завышенную оценку доверия для Украины на конце периода, который анализировался. Это дает основания для предположения, что в Украине действуют еще дополнительные факторы, негативно влияющие на межличностное доверие.

Ключевые слова: межличностное доверие, институциональное доверие, корреляционный анализ, кластерный анализ, нейросетевое моделирования.

JEL Classification: A13, C01, C38, C45.

\title{
Relevance of the purpose and hypothesis of the study
}

The subject of modern studies are various aspects of the socio-economic nature of trust as a mechanism of interpersonal, intergroup, interinstitutional relations. Despite the substantial number of foreign and domestic publications that deal with the problems of trust, the theoretical understanding of this complex and multi-faceted phenomenon only begins (Cook \& al., 2005), (Merkulova, 2014), (Glaeser \& al., 2000), (Cox \& al., 2005). Measurement of personal and institutional trust is the subject of discussions, and empirical studies on this topic are limited.

Two conceptual approaches can be distinguished in the theoretical analysis of trust: individualistic approach and economic and sociological approach (Putman, 2000).

The first assumes that trust is the product of individual (psychological, physical, religious, etc.) personality characteristics. The second approach implies that trust is formed under the influence of economic and social factors, including income, education, etc. The working hypothesis of our study is the assumption of a mixed set of factors that influence the formation of trust.

This set is the goal of the study - identifying the links between social and economic indicators and trust indicators. The following questions were considered in the work: review of definitions, indicators of trust; the working hypotheses of the research are formulated; The choice of factors related to the trust indexes was made; Cluster analysis of the relationship between individual trust indices and economic indicators was implemented; a correlation analysis of the relationship between individual trust indices and socio-cultural indicators was conducted; A neural network was developed 
for modeling the general index of trust based on a well-founded set of economic and socio-cultural indicators.

Definitive aspect. In modern socio-economic studies, the division of trust in the interpersonal, which, in turn, is subdivided into trust to strangers and acquaintances (relatives, friends etc.) and institutional, which is also analyzed in positions - trust in various state and public institutions, etc. These types of trust have their own distinctions that determine the measurement capabilities (Merkulova, 2014).

In general, trust is a measure of confidence that the subject will behave as expected, given the lack of control over the environment in which it operates. "Trust is the expectation of behavior of other individuals that influence the decision of a person in a situation when he must begin to act without knowing if these acts are performed" (quoted in "This trust belongs to interpersonal trust" (Institutional economics, 2005)).

There are separate indices for estimating distinct types of trust, which are calculated based on the respondents' survey results according to a certain scheme with 4 possible answers. The most well-known sociological surveys of the level of trust are General Social Survey (GSS), World Values Survey (WVS), European Social Survey (ESS), Latinobarómetro, and others (Merkulova, 2014). In our study, we used mainly the WVS database (Bjornskov, 2006) and the following indexes that were calculated based on data sources (Trust index WVS. 2018), (Trust index ESS, 2018) for 1981-2014: Human trust index, Family trust index, Neighbor trust index, Strangers trust index, Person trust index, Confidence to the police, Trust to people of another nationality, Trust to people of another religion, Government trust index.

A comparative analysis showed that Ukraine relates to the countries with strong family and foreign credibility, but very weak in government and police trust.

\section{Choice of factors that affect trust}

Economic factors. High confidence in the country is strongly associated with high household incomes. A higher level of trust is closely linked to a lower income inequality. The explanatory reasons remain unclear, but there are several theories. Inequality of income can make it more difficult for people in distinct levels to have a common sense of purpose and trust each other. Another reason is that low level of trust can hinder the development of positive social relationships, which, in turn, contributes to a high inequality of income (OECD, 2011).

In this paper, instead of household income, GDP per capita was selected to analyze how this macroeconomic indicator relates to the level of trust. The GINI index was also taken as an indicator of income inequality.

Socio-cultural factors. Trust in others may be caused by moral or cultural reasons. In addition, religious beliefs may be important since different religions have disparate attitudes to social interactions and state structures.

In (Alesina \& al., 2000), the influence of religion on trust was insignificant, but this work was conducted only for the United States. Other researchers working on interstate examples have found that religious affiliation sometimes affects the quality of government. One of the explanations for this conclusion is based on the attitude of different religions in relation to the common good and social interaction with others, especially to another religion (Alesina \& al., 2000). In this paper, an analysis of the impact of major world religions and the availability of higher education on the level of trust in the country was implemented.

\section{Neural network for the general index of trust}

In order to construct the neural network model, the following steps were undertaken: the formation of a sample of countries; choice of activation function; choice of number of layers; choice of number of neurons in a layer; the choice of the most influential factors (based on sources (Education level, 2018), (GINI data, 2018a), (GINI data. 2018b), (GINI data, 2018c), (GDP, 2018a), (GDP, 2018b), (General Database, 2018), (Trust index, 2018)).

For simulation data from source (Trust index WVS. 2018) for 1997-2014 was used. The sample

included 91 countries for a given time. For analysis, sigmoid was used as an activation function

$$
y=\frac{1}{1+e^{-s}} \text {. }
$$

For the selection of the most noteworthy features, a correlation analysis was carried out (Figure 1). For analysis, Deductor software was used. 


\begin{tabular}{|c|c|c|c|}
\hline \multicolumn{2}{|r|}{ Входные поля } & \multicolumn{2}{|c|}{ Корреляция с выходными полями } \\
\hline N² & Поле & Most people can be trusted & $t$ \\
\hline 4 & GDP & $\square$ & 0,567 \\
\hline 5 & NO & 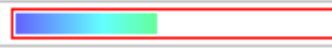 & 0,411 \\
\hline 3 & GINI & \begin{tabular}{|l} 
\\
\end{tabular} & $-0,335$ \\
\hline 10 & Catholic & $\square$ & $-0,306$ \\
\hline 9 & Protestant & 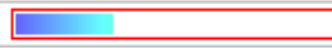 & 0,282 \\
\hline 2 & University - level education, with degr... & 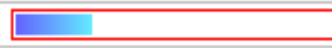 & 0,225 \\
\hline 15 & OTHER & $\square$ & 0,188 \\
\hline 6 & Buddhist & $\square$ & 0,177 \\
\hline 8 & Orthodox & $\square$ & $-0,161$ \\
\hline 7 & Islam & $\square$ & $-0,134$ \\
\hline 12 & Confucianism & $\square$ & $-0,058$ \\
\hline 1 & Year & $\square$ & $-0,037$ \\
\hline 11 & Other Christian & $\square$ & $-0,021$ \\
\hline 13 & Hindu & $\square$ & 0,021 \\
\hline 14 & Jew & - & $-0,001$ \\
\hline
\end{tabular}

Source: author's development

Some indicators have a positive effect, while the other part has a negative effect (Table 1). With the growth of GDP per capita, the percentage of people who have received university education and the reduction of inequality (GINI), the trust index is increasing.

Factors' influence on trust

Table 1

\begin{tabular}{|c|c|}
\hline Positive influence & Negative influence \\
\hline GDP per capita & GINI \\
\hline Atheism & Catholicism \\
\hline Protestantism & Orthodoxy \\
\hline Availability of university education & Islam \\
\hline Other religions & Confucianism \\
\hline Buddhism & Other Christianity \\
\hline Hinduism & Judaism \\
\hline
\end{tabular}

Source: author's development

The influence of religions on the trust index is ambiguous. It is important to point out that only Buddhism, Hinduism and Atheism, have a positive effect on trust.

Indicators that have the highest significance on the trust index: GDP per capita, GINI, religion: atheism - the percentage of people who support this attitude towards religion were selected. The starting point is the general trust index. A neural network was built on a maximum sample of available information. 198 observations were used, where each observation is a country for a specific year in the period 1995-2014. Data from Ukraine were excluded from the sample for a test case for recognition.

Neural network has the following parameters: the number of layers - 1; number of neurons in the layer - 7; activation function - sigmoid; steepness activation function - 1; algorithm - online training; learning speed 0.1; moment - 0.9; Error - 0.05 .

The neural network recognized $89.89 \%$ of the data and $90 \%$ of the test set, indicating that the network is adjusted and can be used for simulation. The maximum error for the data is 0.189 , and the average 0.0193 , for the test set the maximum error is 0.0538 and the average is 0.014 . The scatter plot, where the red lines show a $5 \%$ error, indicates that most of the data is in an acceptable region (Fig. 2).

The most accurate estimates of trust model are provided for the countries represented in Table. 2 


\section{Countries with the best estimate}

Table 2

\begin{tabular}{|l|l|l|c|}
\hline & Most people can be trusted & Estimated & Error \\
\hline 1997 Czech Republic & 27.2 & 27.12118 & $0.29 \%$ \\
\hline 2007 Georgia & 17.6 & 17.52105 & $0.45 \%$ \\
\hline 2007 Taiwan & 24.2 & 24.01968 & $0.75 \%$ \\
\hline 1997 El Salvador & 14.1 & 14.29603 & $-1.39 \%$ \\
\hline 2007 Hong Kong & 40.3 & 40.52066 & $-0.55 \%$ \\
\hline 2007 Norway & 73.7 & 73.33999 & $0.49 \%$ \\
\hline
\end{tabular}

Source: author's development
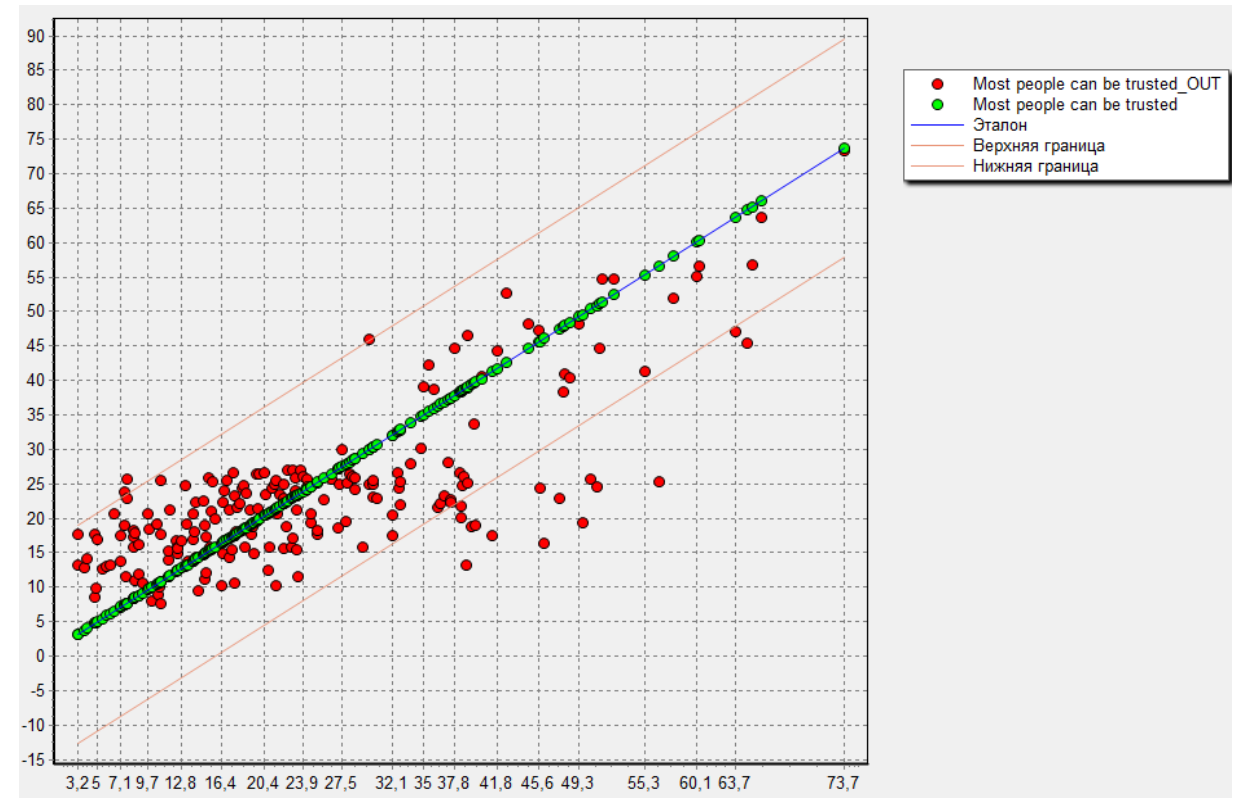

Fig.2 Neural Network scatter plot

Source: author's development

To assess the quality of the model, it was tested on the example of Ukraine - a country that was not part of the working set in the development of the neutron network (Table 3). The deviation of the predicted values ( $\left.T_{\text {data }}\right)$ from the model ( $\left.T_{\text {estimated }}\right)$ shows the error

$$
\text { Error }=\frac{T_{\text {data }}-T_{\text {estimated }}}{T_{\text {data }}} \text {. }
$$

Table 3

Neural Network Errors

\begin{tabular}{|c|c|c|c|}
\hline Year & $\begin{array}{c}\text { Actual value } \\
\text { trust index, \% }\end{array}$ & Estimated value of the trust index, \% & Error, \% \\
\hline 2012 & 23.1 & 26.91 & $-16 \%$ \\
\hline 2007 & 24.5 & 26.73 & $-9 \%$ \\
\hline 1997 & 28.8 & 23.4 & $19 \%$ \\
\hline
\end{tabular}

Source: author's development

The result shows that the error does not exceed $20 \%$; it should also be noted that the model gives an overestimate of confidence at the end of the analyzed period. This gives the ground for the assumption that in Ukraine there are additional factors that negatively affect interpersonal trust. 


\section{Conclusions}

The hypothesis about the influence on the trust of socio-cultural factors, among which the relation to a specific religion was tested. Using correlation analysis and neural network simulations, it has been shown that Protestantism and Catholicism are the most significant religions that affect the general index of interpersonal trust. However, atheism has higher significance level. The constructed neural network model provides satisfactory results in forecasting the general index of trust based on factors: GDP per capita, GINI coefficient, atheism (percentage of population supporting such attitude to religion). The neural network recognized $89.89 \%$ of the data and $90 \%$ of the test set, indicating that the network is adjusted and can be used for simulation. The scatter plot for a $5 \%$ error indicates that most of the data is within an acceptable region.

But it should be noted that the model gives an overestimated assessment of confidence in Ukraine at the end of the analyzed period. This gives the ground for the assumption that in Ukraine there are additional factors that negatively affect interpersonal trust.

\section{References}

1. Alesina, A., and E. La Ferrara, "The Determinants of Trust," NBER working paper 7621, 2000.

2. Cook K.S.,Yamagishi T., Cheshire C., Cooper R., Matsuda M., and Mashima R., "Trust building via risk taking: A cross-societal experiment". Social Psychol. Quart. 2005, 2, 68, 121-142.

3. Merkulova T.V. " Experimental and sociological methods of measuring trust "Scientific works of Donetsk National Technical University. Ser.: Economic. № 1, 2014, 139-148. 2011.

4. OECD, "Trust", in Society at a Glance 2011: OECD Social Indicators, OECD Publishing,

5. Bjornskov, C., "The Multiple Facets of Social Capital," European Journal of Political Economy, 2006, 22(1), 22-40.

6. Glaeser, E., D. Laibson, J. Scheinkman, and Christine Soutter, "Measuring Trust," Quarterly Journal of Economics, 2000, 115(3), 811-846.

7. Trust index. Retrieved from http://www.worldvaluessurvey.org/wvs.jsp

8. Trust index. Retrieved from http://www.europeansocialsurvey.org/

9. Education level. Retrieved from http://www.worldvaluessurvey.org/wvs.jsp

10. GINI data. Retrieved from http://ourworldindata.org/data/growth-and-distribution-ofprosperity/income-inequality/

11. GINI data. Retrieved from http://utip.gov.utexas.edu/data.html

12. GINI data. Retrieved from http://data.worldbank.org/indicator/SI.POV.GINI

13. GDP per capita data. Retrieved from

http://data. worldbank.org/indicator/NY.GDP.PCAP.PP.CD

14. GDP per capita data. Retrieved from: http://www.tradingeconomics.com/

15. General Database. Retrieved from

http://econ.worldbank.org/WBSITE/EXTERNAL/EXTDEC/EXTRESEARCH/0,,contentMDK:20699070 pagePK:64214825 piPK:64214943 theSitePK:469382,00.html

16. Trust index. Retrieved from https://ourworldindata.org/trust\#data-quality-measurement

17. Cox, James C. and Deck, Cary A., On the Nature of Reciprocal Motives. Economic Inquiry, Vol. 43, Issue 3, pp. 623-635, 2005. Available at SSRN: https://ssrn.com/abstract=906257.

18. Institutional economics / red.A.Oleynik. - M.: INFRA-M, 2005. - 704.

19. Putman, R. (2000). Bowling Alone: The Collapse and Revival of American Community. New York: Simon and Schuster.; Uslaner, E.M. (2000). Producing and Consuming Trust. Political Science Quartely 115(4):569-90; Delhey, J. \& Newton, K. (2003). Who Trusts? The Origins of Social in Seven Societies. European Societies 5(2):93-137.

\section{Література}

1. Alesina, A., and E. La Ferrara, "The Determinants of Trust," NBER working paper 7621, 2000.

2. Cook K.S., Yamagishi T., Cheshire C., Cooper R., Matsuda M., and Mashima R., "Trust building via risk taking: A cross-societal experiment". Social Psychol. Quart. 2005, 2, 68, 121-142. 
3. Меркулова Т.В. “Экспериментальный и социологический методы измерения доверия" Наукові праці Донецького національного технічного університету. Сер. : Економічна. № 1, 2014, 139-148.

4. OECD, "Trust", in Society at a Glance 2011: OECD Social Indicators, OECD Publishing, 2011.

5. Bjornskov, C., "The Multiple Facets of Social Capital," European Journal of Political Economy, 2006, 22(1), 22-40.

6. Glaeser, E., D. Laibson, J. Scheinkman, and Christine Soutter, "Measuring Trust," Quarterly Journal of Economics, 2000, 115(3), 811-846.

7. Рівень довіри [Електронний ресурс]: сховище даних. - Режим доступу: http://www.worldvaluessurvey.org/wvs.jsp, вільний.

8. Рівень довіри [Електронний ресурс]: сховище даних. - Режим доступу: http://www.europeansocialsurvey.org/, вільний.

9. Рівень навчання [Електронний ресурс]: сховище даних. - Режим доступу: http://www.worldvaluessurvey.org/wvs.jsp, вільний.

10. GINI data [Електронний ресурс]: сховище даних. - Режим доступу: http://ourworldindata.org/data/growth-and-distribution-of-prosperity/income-inequality/, вільний.

11. GINI data [Електронний ресурс]: сховище даних. - Режим доступу: http://utip.gov.utexas.edu/data.html, вільний.

12. GINI data [Електронний ресурс]: сховище даних. - Режим доступу: http://data.worldbank.org/indicator/SI.POV.GINI, вільний.

13. GDP per capita data [Електронний ресурс]: сховище даних. - Режим доступу: http://data.worldbank.org/indicator/NY.GDP.PCAP.PP.CD, вільний

14. GDP per capita data [Електронний ресурс]: сховище даних. - Режим доступу: http://www.tradingeconomics.com/, вільний.

15. Сховище даних [Електронний ресурс]: сховище даних. - Режим доступу: http://econ.worldbank.org/WBSITE/EXTERNAL/EXTDEC/EXTRESEARCH/0,,contentMDK:20699070 pagePK:64214825 piPK:64214943 theSitePK:469382,00.html, вільний.

16. Рівень довіри [Електронний ресурс]:. - Режим доступу: https://ourworldindata.org/trust\#data-quality-measurement, вільний.

17. Cox, James C. and Deck, Cary A., On the Nature of Reciprocal Motives. Economic Inquiry, Vol. 43, Issue 3, pp. 623-635, 2005. Available at SSRN: https://ssrn.com/abstract=906257.

18. Institutional economics / red.A.Oleynik. - M.: INFRA-M, 2005. - 704.

19. Putman, R. (2000). Bowling Alone: The Collapse and Revival of American Community. New York: Simon and Schuster.; Uslaner, E.M. (2000). Producing and Consuming Trust. Political Science Quartely 115(4):569-90; Delhey, J. \& Newton, K. (2003). Who Trusts? The Origins of Social in Seven Societies. European Societies 5(2):93-137. 